\title{
JUURNAL_RU
}

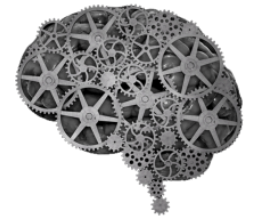

COMPANY GROUP "INTELLEKT"

Жесткова Е.А. ЯрГУ им. П. Г. Демидова Ярославль, Россия

doi: 10.18411/1j2016-5-2-11

\section{Специфика нейминга предприятий индустрии красоты на примере г. Ярославля}

Понятие красоты появилось давно. Исследования в области этимологии утверждают, что само слово «красота» издревле обозначала внешние свойства явлений и предметов, воспринимаемых органами чувств - зрением и слухом. Это явление генетически и органически связано с понятиями практического отношения к предмету (словесные синонимы - здоровый, хороший, добрый и т.д.), либо с его эмоциональной оценкой (приятный, радостный и т.д.)

Первый салон красоты появился относительно недавно - в конце XIX века в австралийском Мельбурне, а началась его история с баночки крема.

В наши дни салонов красоты великое множество, и, несмотря на это, их число продолжает расти. Это вполне оправданно - успех во всех сферах деятельности во многом зависит от нашего внешнего вида, образа, который мы создаем для окружающих.

Нельзя не согласиться с тем, что ввиду популярности предприятий эстетического бизнеса на рынке труда между ними существует жесткая конкуренция. Они делают все возможное, чтобы клиент выбрал именно их услуги, поэтому прибегают к различным способам воздействия. Воздействовать на ум и поведение человека можно различными путями - убеждением, внушением, подкупом, технотронными приемами и другими средствами. Одним из способов воздействия на потребителя является нейминг. 
Нами было отобрано 139 наименований салонов в городе Ярославле. При отборе слов были использованы поисковые системы Яндекс и Google, а также бесплатный справочник организаций «2ГИС», с помощью которых удалось найти необходимый лексический материал. Лучше всего рассмотреть лексику, разделив слова на группы. Нами применено несколько подходов, чтобы наиболее полно и глубоко рассмотреть принципы номинации салонов красоты. В нашем исследовании мы сближаем понятия эргонима, нейминга, наименования и названия.

М. Е. Новичихина обозначает три основания для классификации коммерческой номинации: 1) по степени мотивированности все коммерческие имена подразделяются на мотивированные и немотивированные; 2) по структуре номинации - на однословные и составные; 3) по «степени прозрачности» исследователь предлагает разделять коммерческую номинацию на прямую и непрямую, в первом случае непосредственно называется товар или услуга, непрямая номинация подразумевает отсутствие связи названия с предлагаемым товаром либо соотношение на уровне ассоциаций.

Рассмотрим различные классификации эргонимов, соотнеся их с темой нашей работы.

1)По использованию языка, на котором предъявляется название

a) Русский язык

«Академия +», «Альвер», «Апельсин», «Актуаль», «Будьте красивы»», «Боттичелли», «Виктория», «Виватон», «Веллана», «Визит», «Винтаж», «Весна», «Версаче», «Виктория - 37», «Восьмое желание», «Ваниль», «Гламур», «Глянеиџ», «Глори», «Для всей семьи», «Дивина», «Дама Пик», «Дельта», «Де бон», «Для Вас», «Жанэт», «Жаклин», «Жасмин», «Звездные ногти», «Звездьл», «Зеркало», «Инессис», «Империя», «Ирис», «Кузина», «Кристина», «Каскад», «Кристель, «Ярославль» и др.

б) Иностранный язык

«Artis», «Anna», «Bonito», «Beauty Lab», «Bagira», «Body Studio», «Beauty 
Line», «Chocolate», "Fifa», «Golden Glam», «Hollywood», «Joy», «Kleopatra», «Kristina», «La Coiffure», "Laneche», «Marmalade nail bar \& hair», «Matrix», «Millenium», «Monte Carlo», «Podium», «Paul Mitchell» $и \partial p$.

Использование названий салонов на иностранном языке является средством внушения и придает эмоциональную окраску звучанию, к тому же, как думают некоторые владельцы, смотрится более выигрышно на фоне конкурентов, имитируя заграничную жизнь. Как видим, эргонимов на иностранном языке или же написанных латиницей меньше, чем русскоязычных. Это объясняется тем, что живем мы в России.

2) По структуре номинации

а) однословные (состоят из одного слова)

«Академия +», «Альвер», «Апельсин», «Актуаль», «Боттичелли», «Виктория», «Виватон», «Веллана», «Визит», «Винтаж», «Весна», «Версаче», «Виктория - 37», «Ваниль», «Гламур», «Глянеи», «Глори», «Дивина», «Дельта», «Жанэт», «Жаклин», «Жасмин», «Звездыл», «Зеркало», «Инессис», «Империя», «Ирис», «Кузина», «Кристина», «Каскад», «Кристель», «Красотка», «Катрин», «Классик», «Мармелад», «Манго», «Меланж», «Мадлен», «Медея», «Малина»и ир.

б) составные (состоят из двух и более слов)

«Будьте красивыl», «Восьмое желание», «Для всей семьи», «Дама Пик», «Де бон», «Для Вас», «Звездные ногти», Красивые люди», «Классика жанра», «Люби себя», «Мой салончик», «Мон Шер», «МК», «Магия красотыл», «Молодильные яблоки», «На Московском», «На Гоголя», «На Перекопе», «Парикмахерская на Пушкина», «Пятый элемент» и др.

Большую часть названий составляют однословные. Мы полагаем, что рекламное имя, состоящее из одного слова, гораздо лучше запоминаемо.

3) По «степени прозрачности»

a) прямые

«Будьте красивыл», «Зеркало», «Красивые люди», «Красотка», «Каре», 
«Молодильные яблоки», «Парикмахерская на Пушкина», «Семейная парикмахерская», «Салон красоты «№1》, «Территория красотыл», «Beauty Lab», «Body Studio», «Beauty Line»«Fifa», «La Coiffure», «Marmalade nail bar \& hair», «Paul Mitchell»«Sun Make-up», «World Beauty»,

б) непрямые

«Академия +», «Альвер», «Апельсин», «Актуаль», «Боттичелли», «Виктория», «Виватон», «Веллана», «Визит», «Винтаж», «Весна», «Версаче», «Виктория - 37», «Восьмое желание», «Ваниль», «Гламур», «Глянец», «Глори», «Для всей семьи», «Дивина», «Дама Пик», «Дельта», «Де бон», «Для Вас», «Жанэт», «Жаклин», «Жасмин», «Звездные ногти», «Звезды», «Зеркало», «Инессис», «Империя», «Ирис», «Кузина», «Кристина», «Каскад», «Кристель», «Катрин», «Классик», «Классика жанра», «Клео», «Лаванда», «Лира», «Лента», «Людмила», «Люби себя», «Мармелад», «Манго», «Меланж», «Мадлен», «Медея», «Шелк», «Эйрен», «Элементаль», «Эллада», «Эльберты Ланге», «Юбилейныйџ, «Ярославль»и др.

По «степени прозрачности» преобладают непрямые. Вероятно, для того чтобы создать оригинальность и оторванность от повторяющихся названий. Прямых отсылов к словам «парикмахерская», «салон красоты», «красота», «прическа» и пр. сравнительно немного. Причем владельцы салонов предпочитают выбирать названия, которые звучат изящно , но не имеют ничего общего с индустрией красоты.

Составив классификации классификацию названий салонов красоты, мы заметили, что их названия могут соответствовать или же не соответствовать роду деятельности. Кроме того, из подробного анализа стало понятно, что не всегда названия подобраны удачно по ассоциативному ряду.

Из 139 наименования всего лишь 29 из них оказались мотивированными, а остальные - немотивированными. Можно предположить, что владельцы салонов стремятся найти некую изюминку в названии и выделится выделиться среди конкурентов для привлечения покупателей. Они все чаще называют салоны либо 
женскими именами, либо на иностранный манер, либо в честь известной персоны. Лишь немногие названия салонов оказались со своей историей, которую невозможно было предположить, не пообщавшись с владельцем салона лично.

\section{Литература:}

1. Липов, А.Н. Формообразование в живой природе. Биологические основы красоты / А.Н. Липов // Полигнозис [Электронный ресурс]

2. Фитусси, М. Елена Рубинштейн - женщина, сотворившая красоту [Текст] / М. Фитусси ; [пер. с фр. Е. Кожевниковой]. - М. : Колибри : АзбукаАттикус, 2012. - 398 с. .

3. О классификации эргонимов на материале коммерческих наименований Красноярска [Электронный ресурс]. 